\title{
Detection of Bacterial Pathogens in River Water Using Multiplex-PCR
}

\author{
C. N. Wose Kinge ${ }^{1}$, M. Mbewe ${ }^{2}$ and N. P.Sithebe ${ }^{1}$ \\ ${ }^{1}$ Department of Biological Sciences, School of Environmental and Health Sciences, \\ North-West University, Mafikeng Campus, Mmabatho, \\ 2Animal Health Programme, School of Agricultural Sciences, North-West University, \\ Mafikeng Campus, Mmabatho \\ South Africa
}

\section{Introduction}

The aquatic environments receive a significant number of human microbial pathogens from point and non-point sources of pollution. Point-source pollution enters the environment at different locations, through a direct route of discharge of treated or untreated domestic sewage, industrial effluent and acid mine drainage (State of the Environment Report [SER], 2002). Non-point (or diffuse) sources of pollution comprises up to $80 \%$ of the pollution entering major river systems thus are of significant concern with respect to the dissemination of pathogens and their indicators in water systems. They may be attributable to the run-off from urban and agricultural areas, leakage from sewers and septic systems, insecticides and herbicides from agricultural land, and sewer overflows (Stewart et al., 2008). Although majority of pathogenic microbes can be eliminated by sewage treatment, many end up in the effluent which is then discharged into receiving bodies of water. These pathogenic microbes have been implicated in human diseases linked with the use of contaminated water and food. Adequate sanitation and clean water, being two critical factors in ensuring human health, protects against a wide range of water-related diseases. These include diarrhoea, cholera, trachoma, dysentery, typhoid, hepatitis, polio, malaria, and filariasis (United Nations Department of Public Information [UNDPI], 2005).

Water is a vital natural resource because of its basic role to life, quality of life, the environment, food production, hygiene, industry, and power generation (Meays et al., 2004). With the rapid increase in world population and increased urbanisation, there is a massive strain on the existing water supply and sanitation facilities (UNDPI, 2005). In the developing world, poor access to safe water and inadequate sanitation continues to be a danger to human health (World Health Organisation [WHO], 2004). The water situation, in the African continent, has attracted a lot of concern from all sectors of government as it is estimated that more than 300 million out of the 800 million people who live on the continent are in water-scarce environments (United Nations Educational, Scientific and Cultural Organisation [UNESCO], 2004). In Northern Africa, the present water supply is unstable as population growth and economic development have surpassed the traditional water 
management practices, leading to water scarcity and pollution to a varying degree (UNESCO, 2004). According to Beukman and Uitenweerde (2002), Southern Africa faces very serious water challenges with an estimated half of the population lacking access to portable water and sanitation facilities. They further hinted that, by 2025, countries like Mozambique, Namibia, Tanzania and Zimbabwe will face more water pressures.

The scarcity of water does not only threaten food security, but also the production of energy and environmental integrity. This often results in water usage conflicts between different communities, and water contamination when humans and animals share the same source of water (Kusiluka et al., 2005). According to the Department of Water Affairs - DWA (2000), South Africa is a water scarce region, with $450 \mathrm{~mm}$ rainfall per annum. This is lower than the world's $860 \mathrm{~mm}$ average rainfall. Of the forty-four million people who live in South Africa, 12 million people were without access to portable water supply prior to 1994 (Momba et al., 2006). Although the South African government is making significant progress in ensuring the supply of potable water to all communities, 3.3 and 15.3 million inhabitants of South Africa are still identified to be living without access to potable water and adequate sanitation facilities (Council for Scientific and Industrial Research [CSIR], 2008). A total of $80 \%$ of the population live in the rural areas with the unavailability of potable basic water supplies and proper sanitation facilities (Kasrils, 2004; Reitveld et al., 2009).

Due to the scarcity of water in South Africa, extensive exploitation of water resources such as dams, pools, unprotected rivers and springs for domestic and other water uses, is common, particularly in the rural communities where access to potable water supply is limited (Younes and Bartram, 2001). In many developing countries with inadequate sanitation, faecal contaminations of environmental waters by enteric pathogens are very common and river water is major source of microbial pathogens (Sharma et al., 2010). In this study, we report the use of conventional identification, and multiplex PCR (m-PCR) method that permits the simultaneous detection of water-borne Salmonella, Shigella, E. coli, and Klebsiella bacteria spp. from rivers in the North West province of South Africa. The major rivers in the province include the Molopo, Groot Marico, Elands, Hex, and Crocodile Vaal, Skoonspruit, Harts and Mooi. These rivers are grouped into five catchment areas, which include the Crocodile and Elands, Marico and Hex, Marico and Molopo, Mooi and Vaal, and the Harts (SER, 2002; Department of Water Affairs [DWA], 2007). The water quality in these rivers has been impaired partly due to the frequent contamination of water sources with a number of pathogenic microorganisms from human as well as animal activities, which result in the spread of diarrhoeal diseases (Meays et al., 2004).

\subsection{Bacterial pathogens in the aquatic environment}

Microbial pathogens in water include viruses, bacteria, and protozoa (Girones et al., 2010). Currently, pathogenic bacteria have been identified as the major etiological agent in the majority of the waterborne outbreaks worldwide (WHO 2003; Liang et al., 2006). Bacillary dysentery caused by Shigella bacteria alone is responsible for approximately 165 million cases of bacterial diarrhoeal diseases annually. Of this, 163 million are in developing countries and 1.5 million in industrialized ones accounting for an estimated 1.1 million death cases each year (Sharma et al., 2010). Most members of the genus Arcobacter have been 
isolated from different environmental water sources including surface and ground water. Their presence has been correlated with that of faecal pollution indicators (Collado et al., 2008; Fong et al., 2007; Ho et al., 2006) as well as meat mainly from poultry, pork and beef (Collada et al., 2009; Houf, 2010; Wesley and Miller, 2010). Some members of the genus Arcobacter, like A. butzleri, A. cryaerophilus, and A. skirrowii, have been implicated in animal and human diarrhoeal cases, suggesting a faecal oral route of transmission to humans and animals (Gonzalez et al., 2007). Helicobacter pylori on the other hand, found to be present in surface water and wastewater has been implicated in gastritic, peptic, and duodenal ulcer diseases (Linke et al., 2010; Queralt et al., 2005).

Biofilms in drinking water distribution systems have been reported as possible reservoirs of H. pylori and attempts to culture these cells from water samples have proven unsuccessful (Linke et al., 2010; Percival and Thomas, 2009). Due to the fastidious nature of this bacterium, the lack of standard culture methods for environmental samples, and the controversy in its ability to survive in an infectious state in the environment, very few quantitative studies have been reported (Percival and Thomas, 2009). Legionella pneumophila is a ubiquitous bacterium in natural aquatic environments that can also persist in humancontrolled systems containing water, such as air conditioning and plumbing infrastructures (Steinert et al., 2002). Furthermore, Vibrio vulnificus, an opportunistic human pathogen that cause gastroenteritis, severe necrotizing soft-tissue infections and primary septicaemia, has been found present in fish, shell fish, water, and wastewater. Infection generally, is associated with the ingestion of contaminated seafood and water (Harwood et al., 2004; Igbinosa et al., 2009). More so, the presence of enteric bacteria of the genera Salmonella, Shigella, E.coli and Klebsiella in water has been identified as a major threat to human health and causative agents for many diseases (Leclerc et al., 2001).

Salmonellae are the most frequent agents of bacterial gastroenteritis and typhoid in humans and a prime example of a water- and shell fish-transmitted human pathogen. It is frequently isolated from the marine environment where it can remain viable for several hours (Malorny et al., 2008; Westrell et al., 2009). Contamination with Salmonella has been reported in surface water used for recreational purposes, source of drinking water (Till et al., 2008) and irrigation (Gannon et al. 2004) underlining the possible risk associated to the use of such contaminated water. The typhoid caused by Salmonella enterica serotype Typhi remains an important public health problem in developing countries and the burden of typhoid fever worldwide is further compounded by the spread of multiple drug resistant S. typhi (Kim 2010; Lynch et al., 2009; Srikantiah et al., 2006). The runoff from fields with animal husbandry, and untreated sewage disposal contribute to the presence of Salmonella in natural water resources (Jenkins et al., 2008; Moganedi et al., 2007). Low numbers of Salmonella in food, recreational, surface and potable water sources may pose a public health risk given that their infective dose can be as low as 15-100 CFU (Cobbold et al., 2006; Seo et al., 2006).

Species of Shigella and enteroinvasive Escherichia coli (EIEC) are important human pathogens identified as the major cause of bacillary dysentery (Wanger et al., 1988; Szakál et al., 2003). The infective dose of Shigella cells is very low (101-104 organisms), whereas EIEC strains require a larger infectious dose (between $10^{6}$ and $10^{10}$ organisms) (Rowe and Gross, 1984). Both Shigella spp. and EIEC carry a large invasion plasmid and express a similar set of 
proteins. Both of them are transmitted by direct contact from human to human or via contaminated food and water (Parsot, 1994; Rowe and Gross, 1984). Clinical features of bacillary dysentery caused by EIEC that resemble shigellosis include fever, severe abdominal cramps, malaise, toxemia, and watery diarrhea. The serotype E. coli O157:H7, an emergent pathogen of faecal origin frequently isolated from waters, has been implicated in food and water-borne disease outbreaks (Bavaro, 2009).

Bacteria of the genus Klebsiella are ubiquitous in nature and are a frequent cause of nosocomial infections (Horan et al., 1988). Their non-clinical habitats encompass the gastrointestinal tract of mammals as well as environmental sources such as soil, surface waters, and plants (Bagley, 1985). Environmental isolates have been described as being indistinguishable from human clinical isolates with respect to their biochemical reactions and virulence (Matsen et al., 1974). While the medical significance of Klebsiella obtained in the natural environment is far from clear, such habitats are thought to be potential reservoirs for the growth and spread of these bacteria which may colonize animals and humans (Knittel et al., 1977). Of the five identified Klebsiella species, K. oxytoca and K. Pneumonia, remain the most clinically important opportunistic pathogen, implicated in communityacquired pyogenic liver abscess and bacterial meningitis in adults (Casolari et al., 2005; Haryani et al., 2007; Keynan and Rubinstein, 2007), has been reported to be present in water (Syposs et al., 2005).

\subsection{Methods used in detection of bacterial pathogens in water}

Detection, differentiation, and identification of bacteria can be performed by numerous methods, including phenotypic, biochemical and immunological assays, and molecular techniques. These traditional methods for the detection and enumeration of bacterial pathogens have largely depended on the use of selective culture and standard biochemical methods. This classical microbiological methodology relies on the cultivation of specific bacteria, for example plate counts of coliforms. Drawbacks of these methods include firstly, pathogenic bacteria, which normally occur in low numbers, tend to incur large errors in sampling and enumeration (Fleischer, 1990). Secondly, culture-based methods are timeconsuming, tedious; detect only one type of pathogen, and no valid identification of the pathogen (Szewzyk et al., 2000). Thirdly, many pathogenic microbes in the environment, although viable, are either difficult to culture or are non-culturable (Roszak and Colwell, 1987). Sometimes too, it is often difficult to achieve appropriate enrichment, which makes the work even more tedious.

Moreover, concentrations may be too low for cultural detection but still be high enough to cause infection. These limitations therefore make routine examination of water samples for pathogens like Vibrio cholerae, Shigella dysenteriae, Aeromonas spp. and Campylobacter spp., difficult. Instead, bacterial indicator species like Escherichia coli, which is a normal flora present in very high numbers in the gut of warm-blooded animals, is widely used as an indicator of faecal pollution, to estimate the risk of exposure to other pathogenic microbes present in animal or human wastes (Lund, 1994). However, Escherichia coli as well as some bacterial species like Enterococcus faecalis, once released into freshwater bodies, enter a viable but non-culturable (VBNC) state and express different set of activities, including virulence traits (Lleo et al., 2005). As a result, the current methodology is unsuitable for 
the detection of bacterial pathogens in water and the assessment of their virulence potential. Therefore, a molecular detection method is needed, since such methods are highly specific and sensitive.

Molecular methods used are typically based on the detection and quantification of specific segments of the pathogen's genome (DNA or RNA). To achieve this, the specific segments are subjected to in vitro amplification. These methods allow researchers to speedily and specifically detect microorganisms of public health concern (Girones et al., 2010). Recently, molecular techniques, specifically nucleic acid amplification procedures, immunocapturing, fluorescence in-situ hybridization (FISH), and polymerase chain reaction (PCR) have provided highly sensitive, rapid and quantitative analytical tools for detecting specific pathogens in environmental samples (Watson et al., 2004). These techniques are used to evaluate the microbiological quality of food and water, as well as microbial source-tracking (Albinana-Gimenez et al., 2009; Field et al., 2003; Hundesa et al., 2006). Most applied molecular techniques are based on protocols of nucleic acid amplification, of which the polymerase chain reaction (PCR) is the most commonly used.

PCR is a molecular tool that allows for the amplification of target DNA fragments using oligonucleotide primers in a chain of replication cycles catalysed by DNA polymerase (Taq polymerase) (Rompré et al., 2002). This tool is used for microbial identification and surveillance with high sensitivity and specificity (Watterworth et al., 2005). It has successfully been applied for the detection and identification of pathogenic bacteria in clinical and environmental samples, as well as for the investigation of food and waterborne disease outbreaks (Harakeh et al., 2006; Haryani et al., 2007; Hsu and Tsen, 2001; Riyaz-Ul-Hassan et al., 2004; Shabarinath et al., 2007). The use of quantitative PCR (qPCR) is rapidly becoming established in the environmental sector since it has been shown, in many cases, to be more sensitive than either the bacterial culture method or the viral plaque assay (He and Jiang, 2005). However, molecular protocols, unlike traditional culture-based methods, do not distinguish between viable and non-viable organisms hence the need for more information before replacing the current conventional methods by molecular ones.

Molecular techniques for the specific detection and quantification of bacterial pathogens also offer several advantages over conventional methods: high sensitivity and specificity, speed, ease of standardization and automation. As with the viruses, direct PCR amplification of some bacterial pathogens from water samples is difficult due to the presence of only low numbers of these bacteria in environmental sources. Therefore, an enrichment step is usually required prior to performing a PCR (Noble and Weisberg, 2005). Improved detection of pathogenic E. coli (Ogunjimi and Choudary, 1999) by immuno-capture PCR, and the sensitive detection of Salmonella (Hoorfar et al., 2000) and Campylobacter (Nogva et al., 2000) by real-time PCR have also been developed; but these procedures are all monospecific and are either laborious or very expensive for routine use in water testing laboratories. More recent improvements have allowed simultaneous detection of several microorganisms in a single assay (Maynard et al., 2005; Straub et al., 2005; Marcelino et al., 2006). The use of such multiplex polymerase chain reaction (m-PCR) has provided rapid and highly sensitive methods for the specific detection of pathogenic microbes in the aquatic environment (Kong et al., 2002). 


\subsection{Multiplex polymerase chain reaction ( $m-P C R)$}

Following the application of PCR in the simultaneous amplification of multiple loci in the human dystrophin gene (Chamberlain et al., 1998), multiplex PCR has been firmly established as a general technique. To date, the application of multiplex PCR in pathogen identification, gender screening, linkage analysis, template quantitation, and genetic disease diagnosis is widely established (Chehab and Wall, 1992; Kong et al., 2002; Serre et al., 1991; Shuber et al., 1993). For pathogen identification, PCR analysis of bacteria is advantageous, as the culturing and typing of some pathogens has proven difficult or lengthy. Bacterial multiplexes indicate a particular pathogen among others, or distinguish species or strains of the same genus. An amplicon of sequence conserved among several groups is often included in the reaction to indicate the presence of phylogenetically or epidemiologically similar, or environmentally associated, bacteria and to signal a functioning PCR. Multiplex assays of this set-up distinguish species of Legionella (Bej et al., 1990), Mycobacterium (Wilton and Cousin, 1992), Salmonella (Chamberlain et al., 1998), Escherichia coli, and Shigella (Bej et al., 1991) and major groups of Chlamydia (Kaltenboek et al., 1992) from other genus members or associated bacteria. It has also been shown that multiplex PCR remains the ideal technique for DNA typing because the probability of identical alleles in two individuals decreases with the number of polymorphic loci examined. Reactions have been developed with potential applications in paternity testing, forensic identification, and population genetics (Edwards et al., 1991, 1992; Klimpton et al., 1993). Multiplex PCR can be a twoamplicon system or it can amplify 13 or more separate regions of DNA. It may be the end point of analysis, or preliminary to further analyses such as sequencing or hybridization. The steps for developing a multiplex PCR and the benefits of having multiple fragments amplified simultaneously, however, are similar in each system (Edwards and Gibbs, 1994).

\subsection{Aim/Objectives of the study}

To detect the presence of pathogenic Escherichia coli, Klebsiella, Salmonella, and Shigella species in water samples obtained from rivers in the North-West Province of South Africa, conventional typing and multiplex PCR methods were applied to enriched cultures. The objectives of the study were to use conventional methods to check for the presence and molecular tools to confirm the identity of Escherichia, Klebsiella, Salmonella, and Shigella species in river water. Our prognosis is that the results will emphasize the need for a rapid and accurate detection method for water-borne disease outbreaks and bacterial pathogens in water to protect human health.

\section{Materials and methods}

A total of 54 water samples were collected using sterile $500 \mathrm{~mL}$ McCartney bottles, downstream, midstream, and upstream of the Crocodile, Elands, Hex, Mooi, Vaal, Molopo, Groot Marico, Harts and Skoonspruit rivers between November 2007 and March 2008 (Fig. 1). These rivers form the five major catchments in the province, which are the Crocodile and Eland, Marico and Hex, Marcio and Molopo, Mooi and Vaal, and Harts catchments. Samples collected were transported on ice to the laboratory for analysis. 


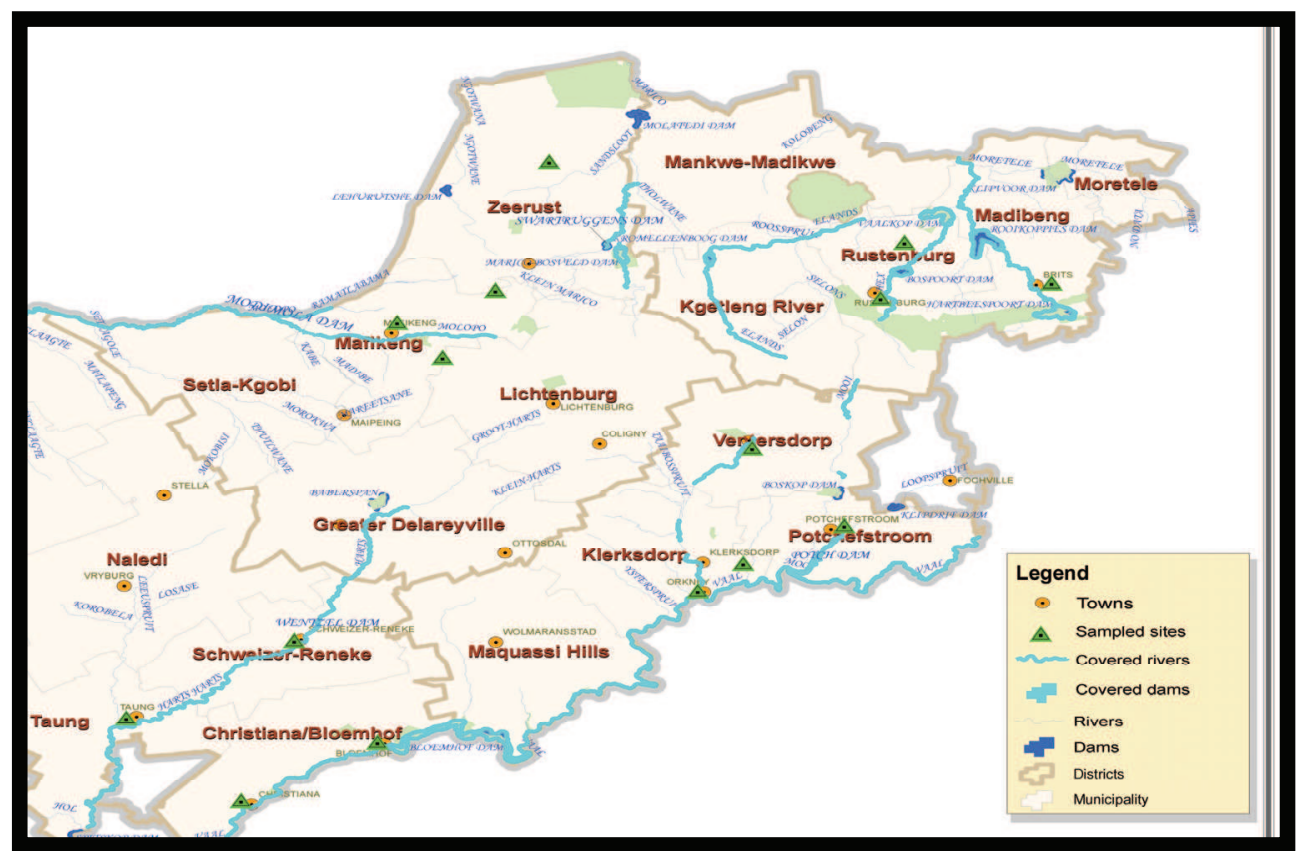

Fig. 1. A cross-section of the North West province map showing the rivers and dams sampled

\subsection{Bacterial reference strains}

Bacterial strains used for the experimental work (Table 1) were American Type Culture Collection (ATCC) cultures. The strains were grown on Nutrient Agar (Biolab, Merck, South Africa) under aerobic conditions at $37^{\circ} \mathrm{C}$ for 24 hours.

\begin{tabular}{ccccccc}
\hline Bacterial Strains & Source & Reference & Mdh & IpaH & IpaB & GapA \\
\hline Salmonella paratyphi & ATCC 9150 & This study & - & - & + & - \\
Salmonella typhi & ATCC 14028 & Hsu and Tsen, 2001 & - & - & + & - \\
Shigella boydii & ATCC 9207 & Wang et al., 1997 & - & + & - & - \\
Shigella sonnei & ATCC 25931 & Wang et al., 1997 & - & + & - & - \\
Klebsiella pneumonia & ATCC 15611 & Lu et al., 2000 & - & - & - & + \\
K. oxytoca & ATCC 43086 & This study & - & - & - & + \\
Escherichia coli & ATCC 25922 & Lu et al., 2000 & - & - & - & - \\
\hline
\end{tabular}

Table 1. Bacterial strains used in the study for evaluation of primer specificity 


\subsection{Selective isolation of Salmonella, Shigella, E. coli and Klebsiella}

Water analysis for Salmonella, Shigella, E. coli and Klebsiella bacteria, was done using the spread plate method (American Public Health Association [APHA], 1998). In brief, 1mL of each water sample was enriched in $9 \mathrm{~mL}$ of $2 \%$ buffered-peptone water (Biolab, Merck Diagnostics, South Africa) and serial dilutions performed. Aliquots of $0.1 \mathrm{~mL}$ of each dilution were plated out on Eosin Methylene Blue (EMB) agar plates (Biolab, Merck Diagnostics, South Africa) for the presumptive isolation of E. coli and Klebsiella, and on Salmonella-Shigella agar for Salmonella and Shigella isolation. All plates were incubated at $37 \mathrm{C}^{\mathrm{C}}$ for 24 hours. Presumptive isolates were sub-cultured on fresh media plates incubated at $37{ }^{\circ} \mathrm{C}$ for 24 hours and then preserved on $2.3 \% \mathrm{w} / \mathrm{v}$ Nutrient agar plates for further analysis.

\subsection{Bacterial Identification using triple sugar iron (TSI) agar test}

All 2992 and 1180 presumptive isolates on EMBA and SSA plates, respectively were Gram stained using the method of Cruikshank et al., (1975) to confirm their morphology as Gram negative rod-shaped bacteria. All Gram negative isolates were subjected to the TSI test, a biochemical test, which distinguishes the Enterobacteriaceae from other intestinal Gramnegative bacilli by the ability of the organisms to catabolise the sugars glucose, lactose and sucrose present at different concentrations in the medium, and the production of acid and gas (Prescott, 2002). The test was performed as previously recommended (United States Pharmacopeia Convention; Inc., 2001). Briefly, isolates were streak-plated on TSI agar slopes and incubated at $37^{\circ} \mathrm{C}$ for 24 hours. The results were interpreted as previously determined by Forbes and Weissfeld (1998).

\subsection{Differentiation of Salmonella, Shigella, E. coli and Klebsiella using conventional serological assay}

All Salmonella, Shigella, E. coli and Klebsiella candidate isolates obtained from culture plates and identified by Triple Sugar Iron [TSI] agar test, were differentiated by conventional serotyping (Ballmer et al., 2007). To test for surface antigens, E. coli Poly D1-D8; Shigella boydii Poly C, C1, C2 and C3, Shigella dysenteriae Poly A Types 1, 2, 3, 4, 5, 6, 7, Shigella sonnie Poly D Phase I and II, Shigella flexneri Poly B Types I, II, III, IV, V, VI; Salmonella O Poly O (Factors A-G, O2, O4, O7, O8, O9, O9, 46, O3, 10, O1, 3, 4) and O1 (Factors O11, O13, O6, 14, O16, O18, O21, O35), Salmonella H Poly Phase 1 and 2; and Klebsiella Capsular Types 1, 2, 3, 4, 5, 6 antisera (Inqaba Biotech, South Africa) were used.

\subsection{DNA extraction}

Genomic DNA was extracted from all positive bacteria cells inoculated in $5 \mathrm{~mL}$ Luria Bertani (LB) broth (Merck, South Africa) following overnight incubation at $37{ }^{\circ} \mathrm{C}$ in a shaker (Doyle and Doyle, 1990). The pellets obtained were re-suspended in $50 \mu \mathrm{L}$ of sterile distilled water. The concentration of the extracted DNA in solution was determined spectrophotometrically (UV Visible spectrophotometer model S-22, Boeco, Germany) by measuring the absorbance at $260 \mathrm{~nm}$. The DNA in solution was used as a template for multiplex PCR. 


\subsection{Oligonucleotide primers and multiplex PCR method}

Oligonucleotide primers used in the study were synthesized by Inqaba Biotech, South Africa. Sequences of the four PCR primer pairs for m-PCR, their corresponding gene targets and size of the expected amplifications are as shown (Table 2). The malate dehyrogenase gene (Mdh) of E. coli (Hsu and Tsen, 2001; Wose Kinge and Mbewe, 2011), the invasive pasmid antigen B gene (IpaB) of Salmonella spp. (Kong et al., 2002), the invasive plasmid antigen gene $\mathrm{H}(\mathrm{IpaH})$ of Shigella spp. (Kong et al., 2002; Wose Kinge and Mbewe, 2010), and the glyceralehye-3-phospahate dehydrogenase gene (GapA) genes for Klebsiella spp. (Diancourt et al., 2005; Wose Kinge and Mbewe, 2011) were simultaneously detected by multiplex polymerase chain reaction (m-PCR) assays. DNA from $50 \mu \mathrm{L}$ extract from enriched cultures was used for PCR amplification in a final volume of $25 \mu \mathrm{L}$. The reaction mixture consisted of $2 X$ PCR Master mix $(0.05 \mu \mathrm{L}$ Taq DNA polymerase, $4 \mathrm{mM} \mathrm{MgCl}, 0.4 \mathrm{mM} \mathrm{dNTPs})$ (Fermentas, Inqaba Biotechnical Industries (Pty) Ltd, South Africa), $0.3 \mu \mathrm{M}$ of IpaB, $0.2 \mu \mathrm{M}$ of IpaH and $1.0 \mu \mathrm{M}$ each of Mdh and GapA genes. PCR amplification was performed in a Peltier Thermal Cycler (model-PTC-220 DYADTM DNA ENGINE; MJ Research Inc. USA) under the following conditions: heat denaturation at $94^{\circ} \mathrm{C}$ for $3 \mathrm{~min}$, followed by 34 cycles of denaturation at $94^{\circ} \mathrm{C}$ for $30 \mathrm{~s}$; annealing at $60^{\circ} \mathrm{C}$ for $60 \mathrm{~s}$ and extension at $72^{\circ} \mathrm{C}$ for $1 \mathrm{~min}$. This was followed by a final extension step at $72^{\circ} \mathrm{C}$ for $7 \mathrm{~min}$ and $4{ }^{\circ} \mathrm{C}$ hold. To create a negative control template DNA was excluded.

\begin{tabular}{|c|c|c|c|c|}
\hline Organism & $\begin{array}{l}\text { Target } \\
\text { gene }\end{array}$ & Primer & Primer sequence $\left(5^{\prime} \rightarrow 3^{\prime}\right)$ & $\begin{array}{l}\text { Expected size } \\
\text { (bp) }\end{array}$ \\
\hline E. coli & $M d h$ & $\begin{array}{l}\text { Mdh F } \\
\text { Mdh R }\end{array}$ & $\begin{array}{l}\text { CGTTCTGTTCAAATGGCCTCAGG } \\
\text { ACTGAAAGGCAAACAGCCAAG }\end{array}$ & 392 \\
\hline Salmonella & $I p a B$ & $\begin{array}{l}\text { IpaB F } \\
\text { IpaB R }\end{array}$ & $\begin{array}{l}\text { GGACTTTTTAAAGCGGCGG } \\
\text { GCCTCTCCCAGAGCCGTCTGG }\end{array}$ & 314 \\
\hline Shigella & IpaH & $\begin{array}{l}\text { IpaH F } \\
\text { IpaH R }\end{array}$ & $\begin{array}{l}\text { CCTTGACCGCCTTTCCGATA } \\
\text { CAGCCACCCTCTGAGGTACT }\end{array}$ & 606 \\
\hline Klebsiella & GapA & $\begin{array}{l}\text { GapA F } \\
\text { GapA R }\end{array}$ & $\begin{array}{c}\text { GTTTTCCCAGTCACGACGTTGTATGAA } \\
\text { ATATGACTCCACTCACG } \\
\text { TTGTGAGCGGATAACAATTTCCTTCAG } \\
\text { AAGCGGCTTTGATGGCT }\end{array}$ & 700 \\
\hline
\end{tabular}

Table 2. Oligonucleotide primers used in this study

\subsection{Electrophoresis and visualization of PCR products}

Following amplification, $10 \mu \mathrm{L}$ of each sample was electrophoresed in a horizontal agarose (LONZA, South Africa) $1 \% \mathrm{w} / \mathrm{v}$ slab gel containing ethidium bromide $(0.1 \mu \mathrm{g} / \mathrm{mL})$ in $1 \mathrm{X}$ TAE buffer (40 mM tris-acetate; $2 \mathrm{mM}$ EDTA, pH8.3). The agarose gel was electrophoresed for six hours at $60 \mathrm{~V}$. The gel was visualized with UV light (Gene Genius Bio Imaging System, SYNGENE model GBOX CHEMI HR). The relative molecular sizes of the PCR products were estimated by comparing their electrophoretic mobility with $100 \mathrm{bp}$ marker (Fermentas O' GeneRuler DNA ladder; Canada). 


\subsection{Specificity of primers}

The specificity of the primers used for multiplex-PCR was confirmed against related enteric bacterial DNA. The DNA was extracted from $5 \mathrm{~mL}$ of overnight bacterial suspensions cultured in Luria Bertani broth as described under section 2.5. The extracted DNA was then stored at $-20^{\circ} \mathrm{C}$ for use in $\mathrm{m}-\mathrm{PCR}$.

\section{Results and discussion}

\subsection{Differentiation of Salmonella, Shigella, E. coli and Klebsiella using conventional serotyping assay}

In order to differentiate the bacterial isolates using surface antigens present, conventional serotyping by slide agglutination was performed using polyvalent antisera. The commercially available typing antisera are not sufficient to recognize all prevalent serotypes of Salmonella, E. coli and Klebsiella spp. In our study, the antisera assay was not used to identify these serotypes, but rather to determine if a given isolate was a member of the genera of interest or not. The percentages of E. coli, Klebsiella, Shigella and Salmonella isolates obtained, showing a positive agglutination to antisera, were calculated for each catchment area and results recorded as contained in Table 3. The results indicate a presence of E. coli, Klebsiella, Shigella and Salmonella spp. in all five catchments areas. According to Table 3, E. coli (the main indicator for faecal contamination) was present in all five catchment samples. The highest was $29 \%$ in the Crocodile and Elands catchment, followed by the Mooi and Vaal catchment with $24 \%$ agglutination with surface antigen specific antisera. The other three catchments were not free of $E$. coli although at lesser levels, comparably.

According to DWA and WHO standards, water meant for irrigation (DWA, 1996) and human consumption (WHO, 2001) should contain no E. coli bacteria. The use of such contaminated water for irrigation as well as direct consumption as it is before treatment would result in the transmission of potentially pathogenic bacteria to humans through contaminated vegetables and other crops eaten raw, as well as milk from grazing cattle. Klebsiella was highest in the Mooi and Vaal followed by Harts catchments with $19 \%$ and $11 \%$, respectively. Podschun et al. (2001) also reported a high percentage (53\%) distribution of Klebsiella spp. from surface water samples, the most common species being K. pneumoniae. Bacteria species of the genera Escherichia and Klebsiella are amongst the group of faecal coliforms. Generally, faecal coliform bacteria inhabit the gastrointestinal tract of all warm and some cold-blooded animals as normal commensals, hence their presence in any given water body is a clear indication of faecal contamination. Although their presence in water cannot be pinpointed to a specific source of faecal contamination, faecal material from human and animal sources can be regarded as high risk due to the possible presence of pathogenic bacteria (Harwood et al., 2000).

High levels of Shigella contamination were also seen in all catchments with $31 \%$ and $41 \%$ in the Crocodile and Elands catchment and Harts catchment, respectively. In general, there was lesser contamination with Salmonella compared to other faecal coliforms in all catchments with a maximum of $8 \%$ in Mooi and Vaal catchment. Water-borne pathogens often occur in reasonably low concentrations in environmental waters. Therefore, some form of filtration and proliferation are needed for pathogen detection (Hsu et al., 2010). Following 
filtration of the sample on membrane filters, bacteria retained on filters can then be detected by culturing in or on selective media. Additional steps, such as biochemical tests, serological assays, and molecular methods, are necessary for confirmation. The isolation and identification of Shigella spp. and E. coli are straightforward and well established (Echeverria et al., 1991, 1992). However, Shigella spp. and entero-invasive E. coli [EIEC] are genetically close and exhibit considerable antigenic cross-reactivity, thus differentiating between them using a single method can be difficult (Cheasty and Rowe, 1983; Lan et al., 2001; Kingombe et al., 2005; Yang et al., 2005).

The $\mathrm{O}$ and $\mathrm{H}$ antigen serotyping method provide important epidemiological information. However it is not appropriate for routine diagnostic use because of its high cost and the labour-intensive requirements (Ballmer et al., 2007). There is, therefore, an urgent need for an accurate and simple detection, identification, and differentiation technique for Shigella spp. and EIEC, especially for epidemiological studies. On the contrary, serotyping is currently the most widely used technique for typing Klebsiella species. It is based mainly on a division according to the K (capsule) antigens (Ørskov and Ørskov, 1984) and shows good reproducibility and capability in differentiating most clinical isolates (Ayling-Smith and Pitt, 1990).

\begin{tabular}{|c|c|c|c|c|}
\hline River Catchments & E. coli $\%$ & Klebsiella \% & Shigella \% & Salmonella \% \\
\hline Crocodile and Elands & 29 & 4 & 37 & 6 \\
\hline Marico and Hex & 9 & 7 & 18 & 4 \\
\hline Marico and Molopo & 9 & 4 & 12 & 1 \\
\hline Mooi and Vaal & 24 & 19 & 15 & 8 \\
\hline Harts & 7 & 11 & 41 & 6 \\
\hline
\end{tabular}

Table 3. Prevalence of E. coli, Klebsiella, Shigella and Salmonella bacteria obtained by serotyping

\subsection{Multiplex PCR}

The m-PCR was designed to target genes specific to the four entero-pathogenic bacteria selected for this study. Results obtained showed the presence of E. coli, Klebsiella, Shigella and Salmonella contamination in the five catchment areas (Table 4). A total of $39 \%$ of E. coli was recorded for the Crocodile and Elands catchment and up to $45 \%$ of Shigella spp. was recovered from the Marico and Hex catchment. The presence of Klebsiella and Salmonella spp. was also observed with $10 \%$ and $11 \%$ in the Mooi and Vaal catchment, respectively. Of these bacteria species, contamination with Shigella was widespread in all catchments. Detection of the IpaH gene, which is present on both the chromosome and the inv plasmid of all Shigella spp., confirmed the presence of this bacterium in water (Hsu and Tsen, 2001). Understanding the ecology of Shigella had been limited mainly due to the lack of suitable techniques to detect the presence of Shigella in environment samples (Faruque et al., 2002). 
In the present study, we used molecular techniques as well as conventional serotyping method to detect Shigella as well as E. coli, Salmonella and Klebsiella spp. in river waters with special reference to virulence genes. We standardized the assay by culturing the environmental water samples and simultaneously conducting m-PCR tests. In a similar study by Faruque et al. (2002) and Sharma et al. (2010), the IpaH gene was used as an indicator tool to detect the presence of Shigella in environmental waters. Fresh contamination of surface water by faecal material of dysentery patients is a possibility in developing countries where sanitation is poor resulting in the presence of Shigella in surface water. Several previous studies have also detected Shigella in surface waters or sewage samples and have indicated that Shigella strains can possibly be transported by surface waters (Alamanos et al., 2000; Faruque et al., 2002; Obi et al., 2004a; Pergram et al., 1998).

Similarly, amplification of the Mdh gene, which codes for malic acid dehydrogenase, a housekeeping enzyme of the citric acid cycle, and reportedly found in all E. coli strains (Hsu and Tsen, 2001), confirmed the presence of both commensal and pathogenic E. coli in the water samples. Although E. coli is usually present as harmless commensals of the human and animal intestinal tracts, pathogenic strains possess virulent factors that enable them to cause diseases and hence, constitute a potential risk to the health of consumers (Kuhnert et al., 2000). For the detection of Salmonella spp. the IpaB gene, which is a virulence gene found on the invasion plasmid of Salmonella spp., was selected for the PCR as it is reportedly present in most Salmonella strains (Kong et al., 2002). Salmonella is isolated from water in lower numbers than indicator bacteria such as faecal coliforms, faecal streptococci and enterococci, which are several orders of magnitude higher (Sidhu and Toze, 2009).

However, low numbers (15-100 colony-forming units [CFU]) of Salmonella in water may pose a public health risk (Jyoti et al., 2009). In the aquatic environment this pathogen has been repeatedly detected in various types of natural waters such as rivers, lakes, coastal waters, estuarine as well as contaminated ground water (Haley et al., 2009; Levantesi et al., 2010; Lin and Biyela, 2005; Moganedi et al., 2007; Theron et al., 2001; Wilkes et al., 2009). Their presence has been attributable to runoff from fields with animal husbandry, addition of untreated sewage from nearby civilization contribute Salmonella in natural water resources (Moganedi et al., 2007; Jenkins et al., 2008). Salmonella contaminated waters might contribute through direct ingestion of the water or via indirect contamination of fresh food to the transmission of this microorganism. Salmonella prevalence in surface water and drinking water has not been uniformly investigated in different countries in recent papers.

Surveys of Salmonella in fresh surface water environment were mainly performed in industrialized nations, particularly in Canada and North America. Reports of Salmonella prevalence in drinking water were instead more frequent from developing nations reflecting the higher concern relating to the use of low quality drinking water in these countries. Overall, the scientific community has mainly recently focused on the prevalence of is microorganism in impacted and non-impacted watersheds (Haley et al., 2009; Jokinen et al., 2011; Patchanee et al., 2010), on the identification of the routes of salmonellae contamination (Gorski et al., 2011; Jokinen et al., 2010, 2011; Obi et al., 2004b; Patchanee et al., 2010), and on the influence of environmental factors on the spread of Salmonella in water (Haley et al., 2009; Jokinen et al., 2010; Meinersmann et al., 2008; Wilkes et al., 2009). 
Although direct consumption of water by humans from these rivers was minimal throughout the study, indirect consumption through fishing was common. This was particularly evident in the Crocodile and Elands, Marico and Molopo, and the Mooi and Vaal catchment areas. This may be a cause for concern because fish in water bodies contaminated with human and animal waste, harbour a considerable number of bacteria such as Salmonella, Clostridium botulinum, Vibrio cholerae, E. coli and other coliforms, which could be transmitted to humans if eaten raw or under-cooked (Jayasinghe and Rajakaruna, 2005). Fish and shellfish accounts for $5 \%$ of individual cases and $10 \%$ of all food-borne illness outbreaks in the United States (Flick, 2008) and not only does fish constitute potential sources of bacteria, they also harbour antibiotic resistant bacteria that could be transmitted to humans resulting in the spread of a pool of antibiotic resistant genes into the environment (Miranda and Zemelman, 2001; Pathak and Gopal, 2005). This also might be compounded by the presence of opportunistic pathogens like Klebsiella species in water with serious health implications for consumers that utilize water directly or indirectly from the rivers, especially high risk patients with impaired immune systems such as the elderly or young, patients with burns or excessive wounds, those undergoing immunosuppressive therapy or those with HIV/AIDS infection. Colonization may lead to invasive infections and on very rare occasions, Klebsiella spp., notably K. pneumoniae and K. oxytoca, may cause serious infections, such as destructive pneumonia (Bartram et al., 2003; Genthe and Steyn, 2006).

\begin{tabular}{|c|c|c|c|c|}
\hline River Catchments & E. coli $\%$ & Klebsiella \% & Shigella $\%$ & Salmonella \% \\
\hline Crocodile and Elands & 39 & 0 & 11 & 6 \\
\hline Marico and Hex & 4 & 6 & 45 & 0 \\
\hline Marico and Molopo & 0 & 6 & 5 & 1 \\
\hline Mooi and Vaal & 15 & 10 & 5 & 11 \\
\hline Harts & 0 & 0 & 23 & 9 \\
\hline
\end{tabular}

Table 4. Prevalence of E. coli, Klebsiella, Shigella and Salmonella bacteria obtained by m-PCR

\subsection{Specificity of primers}

In order to evaluate and verify the specificity of the primers in this study, each primer pair was tested by PCR on DNA templates prepared from a panel of seven different bacterial control strains. The analysis indicated that all primer pairs showed specificities only for their corresponding target organisms (Table 1) and all four sets of PCR primers were targeted at a virulence-associated gene. The Mdh primers specifically amplified a 392bp malic acid dehydrogenase gene fragment from $E$. coli strain obtained from the American Type Culture Collection (Table 1) and 4-39\% of isolates obtained from the different river catchments. The IpaH primers produced a specific 606bp amplimer in all Shigella spp. examined in this study (Table 1; Fig 2. lane 3), which included two species of the genus, viz., S. sonnei and S. boydii, which are known to be pathogenic to humans. In a previously reported study, Kong et al. 
(2002) tested two virulence genes of Shigella, the virA gene and the IpaH gene and obtained more positive amplifications with the IpaH gene when compared with the virA gene.

Although the virA gene was previously reported by Villalobo and Torres (1998) to be specific for virulent Shigella spp., the IpaH gene was found to be more reliable in detecting Shigella spp. in environmental isolates (Kong et al., 2002; Wose Kinge and Mbewe, 2010). The IpaB primers were found to produce a specific 314bp amplimer, in all Salmonella spp. examined, which included S. paratyphi, and S. typhimurium (Table 1; Fig 2. Lanes 7 and 8) as well as $1-11 \%$ of the isolates tested. Similar results were obtained with the GapA primers which generated a 700bp amplimer specific to Klebsiella. The amplimers were confirmed by sequencing (Inqaba Biotech, South Africa) all showed a high percentage of sequence similarity $(>90 \%)$ with published malic acid dehydrogenase, invasive plasmid antigen $\mathrm{H}$ and B, and glyceraldehydes-3-phosphate gene sequences in the GenBank database. Our results therefore, indicated that this particular set of primers were suitable for the specific detection of most general strains of E. coli, Salmonella, Shigella and Klebsiella from water samples.

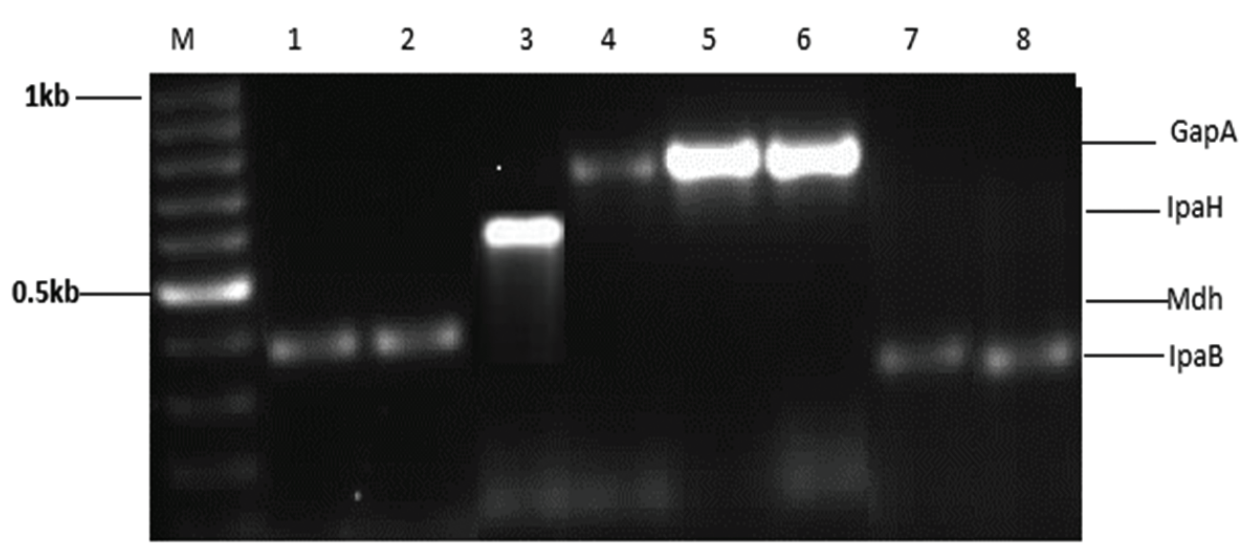

Fig. 2. Electrophoretic analysis of PCR-amplified target genes from six different bacterial pathogens. Mobilities of the different target gene amplicons are indicated on the right. Lane M, 100bp DNA ladder (size marker); lanes 1 and 2, Mdh amplicon of Escherichia coli ATCC 25922; lane 3, IpaH amplicon of Shigella boydii ATCC 9207; lane 4, GapA amplicon of Klebsiella oxytoca ATCC 43086; lanes 5 and 6, GapA amplicon of K. pneumoniae ATCC 15611; lane 7, IpaB amplicon of Salmonella paratyphi ATCC 9150, lane 8, IpaB amplicon of $S$. typhimurium ATCC 14028

\section{Conclusion}

Both conventional and molecular methods successfully identified bacteria of interest, however, the multiplex-PCR assays were sensitive and faster than conventional serotyping methods for detecting E. coli, Salmonella, Shigella, and Klebsiella spp. from river water samples. The 392bp Mdh, 314bp IpaB, 606bp IpaH and 700bp GapA genes were found to be specific and present in the control strains analyzed. Therefore, m-PCR screening of these strains for $M d h, I p a B, I p a H$ and GapA genes should provide a better indicator of possible 
presence of potentially pathogenic E. coli, Salmonella, Shigella and Klebsiella bacteria in river water. The water quality is affected by human activities around the areas, which include industrial processes, mining, agriculture and domestic usage. Thus, the main source of $E$. coli, Salmonella, Shigella and Klebsiella in these rivers may be discharge from wastewater effluent as well as domestic sewage around the catchment areas. Our results indicate that the water-borne and food-borne spread of these pathogens is possible due to drinking water contamination, recreational activities, and fisheries. Since the aquatic environment is implicated as the reservoir for these microorganisms, and consequently responsible for their transmission in humans, it is obvious that detailed studies on the pathogenic potential of the environmental strains will certainly contribute to understanding the virulence properties of these bacteria and to establish the importance of these significant pathogens of aquatic systems. The results thus emphasize the need for the implementation of a rapid and accurate detection method in cases of water-borne disease outbreaks and the need for more rapid detection of bacterial pathogens in water to protect human health. The ability to rapidly monitor for various types of microbial pathogens would be extremely useful not only for routine assessment of water quality to protect public health, but also allow effective assessments of water treatment processes to be made by permitting pre- and post-treatment waters to be rapidly analyzed.

\section{References}

Alamanos, Y., Maipa, V., Levidiotou, S., Gessouli, E. (2000). A community waterborne outbreak of gastro-enteritis attributed to Shigella sonnei. Epidemiol. Infect. 125, pp. (499-503)

Albinana-Gimenez, N., Miagostovich, M., Calgua, B., Huguet, J.M., Matia, L., \& Girones, R. (2009). Analysis of adenoviruses and polyomaviruses quantified by qPCR as indicators of water quality in source and drinking water-treatment plants. Water Res. 43, pp. (2011-2019)

APHA. (1998). Standard methods for the examination of Water and Wastewater, 19th Ed. Amer. Public Health Assoc. Washington DC.

Ayling-Smith, B., \& Pitt, TL. (1990). State of the art in typing: Klebsiella species. J. Hosp. Infect. 16, pp. (287-295)

Bagley, ST. (1985). Habitat association of Klebsiella species. Infect. Control, 6, pp. (52-58)

Ballmer, K., Korczak, BM., Kuhnert, P., Slicker, P., Ehricht, R., \& Hächler, H. (2007). Fast DNA serotyping of Escherichia coli by use of an oligonucleotide microassay. J. Clin. Microbiol. 45, 2, pp. (370-379)

Bartram, J., Chartier, Y., Lee, JV., Pond, K., \& Surman-Lee S (Eds) (2007): Legionella and the Prevention of Legionellosis. WHO Press, World Health Organization, Geneva, Switzerland.

Bartram, J., Cotruvo, J., Exner, M., Fricker, C., \& Glasmacher, A. (2003). Heterotrophic plate counts in drinking water safety: the significance of HPCs for water quality and human health. WHO Emerging Issues in Water and Infectious Disease Series. London, IWA Publishing.

Bavaro, MF. (2009). Escherichia coli O157: what every internist and gastroenterologist should know. Curr. Gastroenterol. Rep. 11, 4, pp. (301-306) 
Bej, AK., Mahbubani, MH., Miller, R., DiCesare, JL., Haft, L., \& Atlas, RM. (1990). Multiplex PCR amplification and immobilized capture probes for detection of bacterial pathogens and indicators in water. Mol. Cell. Prob. 4, pp. (353-365).

Bej, AK., McCarty, SC., \& Atlas, RM. (1991). Detection of coliform bacteria and Escherichia coli by multiplex polymerase chain reaction: Comparison with defined substrate and plating methods for water quality monitoring. Appl. Environ. Microbiol. 57, pp. (1473-1479)

Beukman, R. \& Uitenweerde, T. (2002). Water Demand Management Phase II. International Conservation Union, Pretoria, pp. (12)

Casolari, C.., Pecorari, M., Fabio, G., Cattani, S., Venturelli, C., Piccinini, L., Tamassia, M.G., Gennari, W., Sabbatini, A.M., Leporati, G., Marchegiano, P., Rumpianesi, F., \& Ferrari, F. (2005). A simultaneous outbreak of Serratia marcescens and K. pneumoniae in a neonatal intensive care unit. The J. Hosp. Infec. 61, pp. (312-320)

Chamberlain, JS., Gibbs, RA., Ranier, JE., Nguyen, PN., \& Caskey, CT. (1988). Deletion screening of the Duchenne muscular dystrophy locus via multiplex DNA amplification. Nucleic Acids Res. 16, pp. (11141-11156).

Cheasty, T., \& Rowe, B. (1983). Antigenic relationships between the enteroinvasive Escherichia coli $\mathrm{O}$ antigens O28ac, O112ac, O124, O136, O143, O144, O152, and O164 and Shigella $\mathrm{O}$ antigens. J. Clin. Microbiol. 17, pp. (681-684)

Chehab, FF., \& Wall, J. (1992). Detection of multiple cystic fibrosis mutations by reverse dot blot hybridization: A technology for carrier screening. Hum. Genet. 89, pp. (163168)

Cobbold, RN., Rice, DH., Davis, MA., Besser, TE., \& Hancock, DD. (2006). Long-term persistence of multidrug-resistant Salmonella enterica serovar Newport in two dairy herds. J. Amer. Vet. Med. Assoc. 228, pp. (585-91)

Collado, L., Guarro, J., \& Figueras, MJ. (2009) Prevalence of Arcobacter in meat and shellfish. J. Food. Prot. 72, pp. (1102- 1106)

Collado, L., Inza, I., Guarro, J., \& Figueras, M.J. (2008) Presence of Arcobacter spp. in environmental waters correlates with high levels of fecal pollution. Environ. Microbiol. 10, pp. (1635-1640)

Collie, T.K., Strom, M.S., Sinigalliano, C.D., Moeller, P.D., \& Holland, A.F. (2008). The coastal environment and human health: microbial indicators, pathogens, sentinels and reservoirs. Environ. Health, 7, 2, pp. (S3)

Cruikshank, R., Duguid, JP., Marmoin, BP.,\& Swain, RH. (1975). Medical Microbiology, 12th ed. Longman, New York. 2, pp. (3-4)

CSIR. (2008). Water Quality and Pollution: Parliamentary Portfolio Committee on Water Affairs and Forestry.

Diancourt, L., Passet, V., Verhoef, J., Grimont, P.A., \& Brisse, S. (2005). Multilocus sequence typing of Klebsiella pneumoniae nosocomial isolates. J. Clin. Microbiol. 42, 8, pp. (4178-4182)

Doyle, JJ., \& Doyle, JL. (1990). A rapid total DNA preparation procedure for fresh plant tissue. Focus, 12, pp. (13-15).

DWA. (2000). Water use authorisation process for individual applications, DWAF, Edition 1 final draft for implementation and use, revision 3, December 2000.

DWA. (2007). Integrated Vaal River system WMR studies. Department of Water Affairs and Forestry, Pretoria. 
Echeverria, P., Sethabutr, O., \& Pitarangsi, C. (1991). Microbiology and diagnosis of infections with Shigella and enteroinvasive Escherichia coli. Rev. Infect. Dis. 13, Suppl. 4, pp. (S220-S225)

Echeverria, P., Sethabutr, O., Serichantalergs, O., Lexomboon, U., \& Tamura, K. (1992). Shigella and enteroinvasive Escherichia coli infections in households of children with dysentery in Bangkok. J. Infect. Dis. 165, pp. (144-147)

Edwards, A., Civitello, A., Hammond, HA., \& Caskey, CT. (1991). DNA typing and genetic mapping with trimeric and tetrameric tandem repeats. Am. ]. Hum. Genet. 49, pp. $(746-756)$

Edwards, A., Hammond, HA., Jin, L., Caskey, CT., \& Chakroborty, R. (1992). Genetic variation at five trimeric and tetrameric tandem repeat loci in four human population groups. Genomics, 12, pp. (241-253)

Edwards, MC., \& Gibbs, RA. (1994). Multiplex PCR: advantages, development and applications. Genome Res. 3, pp. (S65-S75)

Faruque, SM., Khan, R., Kamruzzaman, M., Yamasaki, S., Ahmad, QS., Azim, T., Nair, GB., Takeda, Y., \& Sack, DA. (2002). Isolation of Shigella dysenteriae type 1 and S. flexneri strains from surface waters in Bangladesh: comparative molecular analysis of environmental Shigella isolates versus clinical strains. Appl. Environ. Microbiol. 68, pp. (3908-3913)

Field, KG., Bernhard, AE., \& Brodeur, TJ. (2003). Molecular approaches to microbiological monitoring: faecal source detection. Environ. Monit. Assess. 81, pp. (313-326)

Fleisher, JM. (1990). Conducting recreational water quality surveys: some problems and suggested remedies. Mar Pollut Bull. 21, 12, pp. (562-7)

Flick, GJ. (2008). Microbiological safety of farmed fish. Global Aquaculture Advocate, pp. (33-34)

Fong, TT., Mansfield, LS., Wilson, DL., Schwab, DJ., Molloy, SL., \& Rose, JB. (2007). Massive microbiological groundwater contamination associated with a waterborne outbreak in Lake Erie, South Bass Island, Ohio. Environ. Health Perspect. 115, 6, pp. (856-864)

Forbes, S., \& Weissfeld, F. (1998). Bailey and Scott's diagnostic microbiology, 10 th Ed. Mosby, Inc., St. Louis, Mo. Harakeh, S., Yassine, H., El-Faidel, M. (2006). Antibiotic resistant patterns of Escherichia coli and Salmonella strains in the aquatic Lebanese environments. Environ. Pollut. 143, pp. (269-277)

Gannon, VP., Graham, T., Read, S., Ziebell, K., Muckle, A., \& Mori, J., et al. (2004). Bacterial pathogens in rural water supplies in Southern Alberta, Canada. J. Toxicol. Environ. Health, 67, 20-22, pp. (1643-1653)

Genthe, B., \& Steyn, M. (2006). Good intersectoral water governance- a Southern African decision-makers guide. Chapter on Health and Water. CSIR/NRE/WR/EXP/2006/0047/A.

Girones, R., Ferrus, MA., Alonso, JL., Rodriguez-Manzano, J., Correa AA., Calgua, B., Hundesa, A., Carratala, A., \& Bofill- Mas, S. (2010). Molecular detection of pathogens in water- The pros and cons of molecular techniques. Water Res. 44, pp. (4325-4339).

González, A., Botella, S., Montes, RM., Moreno, Y., \& Ferrús, M.A. (2007). Direct detection and identification of Arcobacter species by multiplex PCR in chicken and wastewater samples from Spain. J. Food Prot. 70, (341-347) 
Gorski, L., Parker, CT.,Liang, A., Cooley, MB., Jay-Russell, MT., Gordus, AG. (2011). Prevalence, distribution and diversity of Salmonella enterica in a major produce region of California. Appl. Environ. Microbiol. doi: 10.1128/AEM.02321-10.

Haley, B.J., Cole, DJ., \& Lipp, EK. (2009). Distribution, diversity and seasonality of waterborne Salmonella in a rural watershed. Appl. Environ. Microbiol. 75, pp. (1248-1255)

Haley, BJ., Cole, DJ., \& Lipp, EK. (2009). Distribution, diversity and seasonality of waterborne Salmonella in a rural watershed. Appl. Environ. Microbiol. 75, pp. (1248-1255)

Harakeh, S., Yassine, H., \& EL- Fadel, M. (2006). Antimicrobial resistant patterns of Escherichia coli and Salmonella strains in the aquatic Lebanese environments. Environ. Pol. 143, 2, pp. (269-277)

Harwood, VJ., Gandhi, JP., \& Wright, AC. (2004). Methods for isolation and confirmation of Vibrio vulnificus from oysters and environmental sources: a review. J. Microbiol. Methods, 59, pp. (301-316)

Harwood, VJ., Whitlock, J., \& Withington, V. (2000). Classification of antibiotic resistance patterns of indicator bacteria by discriminant analysis: use in predicting the sources of faecal contamination in subtropical waters. Appl. Environ. Microbiol. 66, 9, pp. (3698-3704)

Haryani, Y., Noorzaleha, A.S., Fatimah, A.B., Noorjahan, B.A., Patrick, G.B., Shamsinar, A.T., Laila, R.A.S., \& Son, R. (2007). Incidence of Klebsiella pneumoniae in street foods sold in Malaysia and their characterization by antibiotic resistance, plasmid profiling, and RAPD-PCR analysis. Food Cont. 18, pp. (847-853)

He, J., \& Jiang, S. (2005). Quantification of enterococci and human adenoviruses in environmental samples by real-time PCR. Appl. Environ. Microbiol. 71, 5, pp. (22502255)

Ho, HT., Lipman, LJ., \& Gaastra, W. (2006) Arcobacter, what is known and unknown about a potential food-borne zoonotic agent!. Vet. Microbiol. 115, pp. (1-13)

Hoorfar, J., Ahrens, P., \& Radstrom, P. (2000). Automated 5'Nuclease PCR Assay for Identification of Salmonella enterica. J Clin Microbiol. 38, 9, pp. (3429-35)

Horan, T., Culver, D., Jarvis, W., Emori, G., Banerjee, S., Martone, W., \& Thornsberry, C. (1988). Pathogens causing nosocomial infections. Antimicrob. Newsl. 5, pp. (65-67)

Houf, K. (2010) Arcobacter. In: Dongyou, L. (Ed.), Molecular detection of foodborne pathogens, CRC Press, New York, USA, pp. (289-306)

Hsu, B-M., Wu, S-F., Huang, S-W., Tseng, Y-J., Chen, J-S., Shih, F-C., \& Ji, D-D. (2010). Differentiation and identification of Shigella spp. and enteroinvasive Escherichia coli in environmental waters by a molecular method and biochemical test. Water Res. 44, pp. (949-955)

Hsu, S-C., \& Tsen, H-Y. (2001). PCR primers designed from malic acid dehydrogenase gene and their use for detection of Escherichia coli in water and milk samples. Int. J. Food Microbiol. 64, pp. (1-11)

Hundesa, A., Maluquer de Motes, C., Bofill-Mas, S., AlbinanaGimenez, N., \& Girones, R. (2006). Identification of human and animal adenoviruses and polyomaviruses for determination of sources of fecal contamination in the environment. Appl. Environ. Microbiol. 72, pp. (7886-7893)

Igbinosa, EO., Obi, LC., \& Okoh, AI. (2009). Occurrence of potentially pathogenic vibrios infinal effluents of a wastewater treatment facility in a rural community of the Eastern Cape Province of South Africa. Res. Microbiol. 160, 8, pp. (531-537) 
Jayasinghe, PS., \& Rajakuruna, RMAGG. (2005). Short Communication: Bacterial contamination of fish sold in fish markets in the Central province of Sri Lanka. J. Nat. Sci. Foundation Sri Lanka, 33, 3, pp. (219-221)

Jenkins, MB., Endale, DM., \& Fisher, DS. (2008) Most probable number methodology for quantifying dilute concentrations and fluxes of Salmonella in surface waters. J Appl Microbiol, 104, pp. (1562-8)

Jokinen, C., Edge, TA., Ho, S., Koning, W., Laing, C., Mauro, W., et al. (2011). Molecular subtypes of Campylobacter spp., Salmonella enterica, and Escherichia coli O157:H7 isolated from fecal and surface water samples in the Oldman River watershed, Alberta, Canada. Water Res. 45, pp. (1247-1257)

Jyoti, A., Ram, S., Vajpayee, P., Singh, G., Dwivedi, PD., Jain, SK., \& Shanker, R. (2009). Contamination of surface and potable water in South Asia by Salmonellae: Cultureindependent quantification with molecular beacon real-time PCR. Sci. Total Environ. 408, 6, pp. (1256-1263)

Kaltenboek, B., K.G. Kansoulas, and J. Storz. 1992. Two-step polymerase chain reactions and restriction endonuclease analyses detect and differentiate ompA DNA of the Chlamydia spp. I. Clin. Microbiol. 30, pp. (1098-1104)

Kasrils, R. (2004). A decade of delivery. Minister of Water Affairs and Forestry.

Keynan, Y., \& Ruinstein, E., 2007. The emerging face of K. pneumoniae infections in the community. Int. J. Antimicrob. Agents. 30, pp. (385-389)

Kim, HM., Hwang, CY., \& Cho, BC. (2010). Arcobacter marinus sp. nov. Int. J. Syst. Evol. Microbiol. 60, pp. (531-536)

Kingombe, CI., Cerqueira-Campos, M-L., \& Farber, JM. (2005). Molecular strategies for the detection, identification and differentiation between enteroinvasive Escherichia coli and Shigella spp. J. Food Prot. 68, 2, pp. (239-245)

Klimpton, CP., Gill, P., Walton, A., Urquhart, A., Millican, E.S., \& Adams, M. (1993). Automated DNA profiling employing multiplex amplification of short tandem repeat loci. PCR Methods Applic. 3, pp. (13-21)

Knittel, MD., Seidler, RJ., Eby, C., \& Cabe, LM. (1977). Colonization of the botanical environment by Klebsiella isolates of pathogenic origin. Appl. Environ. Microbiol.34, pp. (557-563)

Kong, RYC., Lee, SKY., Law, TWF., Law, SHW., \& Wu, RSS. (2002). Rapid detection of six types of bacteria pathogens in marine waters by multiplex PCR. Water Res. 36, pp. (2802-2812)

Kuhnert, P., Boerlin, P., \& Frey, J. (2000). Target genes of virulence assessment of Escherichia coli isolates from water, food and environment. Fed. European Microbiol. Soc. Rev. 24, pp. (107-117)

Kusiluka, LJM., Karimuribo, ED., Mdegela, RH., Luoga, EJ., Munishi, PKT., Mlozi, MRS., \& Kambarage, DM. (2005). Prevalence and impact of water-borne zoonotic pathogens in water, cattle and humans in selected villages in Dodoma Rural and Bagamoyo districts, Tanzania. Phy. Chem. Earth, 30, pp. (818-825)

Lan, R., Lumb, B., Ryan, D., Reeves, PR. (2001). Molecular evolution of large virulence plasmid in Shigella clones and enteroinvasive Escherichia coli. Infect. Immun. 69, pp. (6303-6309) 
LeClerc, H., Mossel, DAA., Edberg, SC., \& Struijk, CB. (2001). Advances in the bacteriology of the coliform group: Their suitability as markers of microbial water safety. Ann. Rev. Microbiol. 55, (201-234)

Levantesi, C., LaMantia, R., Masciopinto, C., Böckelmann, U., Ayuso-Gabella, MN., \& Salgot, M. (2010). Quantification of pathogenic microorganisms and microbial indicators in three wastewater reclamation and managed aquifer recharge facilities in Europe. The Sci. Total Environ. 408, 21, pp. (4923-4930)

Liang, JL., Dziuban, EJ., Craun, GF., Hill, V., Moore, MR., Gelting, RJ., Calderon, RL., Beach, MJ., \& Roy, SL. 2006. Surveillance for waterborne disease and outbreaks associated with drinking water and water not intended for drinking - United States, 20032004. MMWR Surveillance Summit 2006, 55, pp. (5512-5561)

Lin, J., \& Biyela, PT. (2005). Convergent acquisition of antibiotic resistance determinants amongst the Enterobacteriaceae isolates of the Mhlathuze River, KwaZulu-Natal (RSA). Water SA. 31, 2, pp. (0378-4738), ISSN

Linke, S., Lenz, J., Gemein, S., Exner, M., \& Gebel, J. (2010). Detection of Helicobacter pylori in biofilms by real-time PCR. Int. J. Hyg. Environ. Health, 213, pp. (176-182)

Lleo, MM., Bonato, B., Benedetti, D., \& Canepari, P. (2005). Survival of enterococcal species in aquatic environments. FEMS Microbiol. Ecol. 54, pp. (189-196)

Lund, V. (1994). Evaluation of Escherichia coli as an indicator for the presence of Campylobacter jejuni and Yersinia enterocoliticain chlorinated and untreated oligotrophic lake water. Abstract HRM37, Water Quality International 94. IAWQ 17 Biennial International Conference, Budapest, Hungary, 24-29 July 1994.

Lynch, MF., Blanton, EM., Bulens, S., Polyak, C., Vojdani, J., \& Stevenson, J. (2009). Typhoid fever in the United States, 1999-2006. J. Amer. Med. Assoc. 302, 8, pp. (852-869)

Malorny, B., Löfström, C., Wagner, M., Krämer, N., \& Hoorfar, J. (2008). Enumeration of Salmonella bacteria in food and feed samples by real-time PCR for quantitative microbial risk assessment. Appl Environ Microbiol, 74, pp. (1299- 304)

Marcelino, L.A., Backman, V., Donaldson, A., Steadman, C., Thompson, J.R., Preheim, S.P., Lien, C., Lim, E., \& Veneziano, D. (2006). Accurately quantifying low-abundant targets amid similar sequences by revealing hidden correlations in oligonucleotide microarray data. Polz MF. Proc. Natl. Acad. Sci. U. S. A. 103, 37, pp. (13629-13634)

Matsen, JM., Spindler, JA., \& Blosser, RO. (1974). Characterization of Klebsiella isolates from natural receiving waters and comparison with human isolates. Appl. Microbiol. 28, pp. (672-678)

Maynard, C., Berthiaume, F., Lemarchand, K., Harel, J., Payment, P., Bayardelle, P., Masson, L., \& Brousseau, R. (2005). Waterborne pathogen detection by use of oligonucleotide-based microarrays. Appl. Environ. Microbiol. 71, 12, pp. (8548-8557)

Meays, C., Broersma, K., Nordin, R., \& Mazumder, A. (2004). Source tracking faecal bacteria critical review of current methods. J. Environ. Man. 73, pp. (71-79)

Meinersmann, RJ., Berrang, ME., Jackson, CR., Fedorka-Cray, P., Ladely, S., \& Little, E. (2008). Salmonella, Campylobacter and Enterococcus spp.: Their antimicrobial resistance profiles and their spatial relationships in a synoptic study of the Upper Oconee River basin. Microbial Ecology, 55, 3, pp. (444-452)

Miranda, CD., \& Zemelman, R. (2001). Antibiotic resistant bacteria in fish from concepción bay, Chile. Marine Pol. Bulletin, 42, 11, pp. (1096-1102) 
Moganedi, KLM., Goyvaerts, EMA., Venter, SN., \& Sibara, MM. (2007). Optimisation of the PCR-invA primers for the detection of Salmonella in drinking and surface waters following a pre-cultivative step. Water SA. 33, 2, pp. (195-201)

Momba, MNB., Tyafa, Z., Makala, N., Brouekaert, BM., \& Obi, CL. (2006). Safe drinking water is still a dream in the rural areas of South Africa. Case study: The Eastern Cape Province. Water SA. 32, 5, pp. (715-720)

Noble, RT., \& Weisberg, SB. (2005). A review of technologies for rapid detection of bacteria in recreational waters. J. Water Health, 3, 4, pp. (381-392)

Nogva, HK., Bergh, A., Holck, A., \& Rudi, K. (2000). Application of the 50-nuclease PCR assay in evaluation and development of methods for quantitative detection of Campylobacter jejuni. Appl Environ Microbiol. 6, 9, pp. (4029- 36)

Obi, CL., Bessong, PO., Momba, MNB., Potgieter, N., Samie, A., \& Igumbor, E.O. (2004a). Profiles of antibiotic susceptibilities of bacterial isolates and physico-chemical quality of water supply in rural Venda communities, South Africa. Water SA. 30, 4, pp. (515-520)

Obi, CL., Potgieter, N., Musie, EM., Igumbor, EO., Bessong, PO., Samie, A. (2004b). Human and environmental-associated non-typhoidal Salmonella isolates from different sources in the Venda region of South Africa. Proceedings of the 2004 Water Institute of Southern Africa (WISA), Biennial Conference, May 2004.

Ogunjimi, AA., \& Choudary, PV. (1999). Adsorption of endogenous polyphenols relieves the inhibition by fruit juices and fresh produce of immuno-PCR detection of Escherichia coli O157: H7. FEMS Immunol Med Microbiol. 23, 3, pp. (213-20)

Ørskov, I., \& Ørskov, F. (1984). Serotyping of Klebsiella. Methods Microbiol. 14, pp. (143-164)

Parsot, C. (1994). Shigella flexneri: genetics of entry and intercellular dissemination in epithelial cells. In: Dangl, J.L. (Ed.), Bacterial Pathogenesis of Plants and Animals. Curr. Top. Microbiol. Immunol. 192, pp. (217-241)

Pathak, SP., \& Gopal, K. (2005). Occurrence of antibiotic and metal resistance in bacteria from organs of river fish. Environ. Res. 98, pp. (100-103)

Percival, SL., \& Thomas, JG. (2009). Transmission of Helicobacter pylori and the role of water and biofilms. J. Water Health, 7, 3, pp. (469-477)

Pergram, GC., Rollins, N., \& Esprey, Q. (1998). Estimating the costs of diarrhoea and epidemic dysentery in KwaZulu- Natal and South Africa. Water SA. 24, 1, pp. (1120)

Podschun, R., Pietsch, S., Holler, C., \& Ullmann, U. (2001). Incidence of Klebsiella species in surface waters and their expression of virulence factors. Appl. Environ. Microbiol. 67,7 , pp. (3325-3327)

Prescott, H. (2002). Laboratory exercise in Microbiology. Smith publishers, New York. $5^{\text {th }}$ Ed. pp. (133)

Queralt, N., Bartolomé , R., \& Araujo, R. (2005). Detection of Helicobacter pylori DNA in human faeces and water with different levels of faecal pollution in the north-east of Spain. J. Appl. Microbiol. 98, pp. (889-895)

Reitveld, LC., Haarhoff, J., \& Jagals, P. (2009). A tool for technical assessment of rural water supply systems in South Africa. Phy. Chem. Earth, 34, pp. (43-49)

Riyaz-Ul-Hassan, S., Verma, V., \& Qazi, G.N. (2004). Rapid detection of Salmonella by polymerase chain reaction. Molecul. Cellul. Probes, 18, pp. (333-339) 
Rompré, A., Servais, P., Baudart, J., de-Roubin, M-R., \& Laurent, P. (2002). Detection and enumeration of coliforms in drinking water: current methods and emerging approaches. J. Microbiol. Methods 49, pp. (31-34)

Roszak, DB., \& Colwell, RR. (1987). Survival strategies of bacteria in the natural environment. Microbiol. Rev. 51, pp. (365- 79)

Rowe, B., \& Gross, RJ. (1984). Facultatively anaerobic Gram negative rods. Genus II. Shigella. In: Krieg, NR., Holt, JG. (Eds.), Bergey's Manual of Systematic Bacteriology. Williams \& Wilkins, Baltimore, MD, pp. (423-427)

Seo, KH., Valentin-Bon, IE., \& Brackett, RE. (2002). Detection and enumeration of Salmonella enteritidis in homemade ice cream associated with an outbreak: comparison of conventional and real-time PCR methods. J Food Prot. 69, pp. (639-43)

SER. (2002). State of Emergency Report, North West Province, South Africa.

Serre, JL., Taillandier, A., Mornet, E., Simon-Bouy, B., Boue, J., \& Boue, A. (1991). Nearly $80 \%$ of cystic fibrosis heterozygotes and $64 \%$ of couples at risk may be detected through a unique screening of four mutations by ASO reverse dot blot. Genomics 11, pp. (1149-1151)

Shabarinath, S., Sanath Kumar, H., Khushiramani, R., Karunasagar, I., \& Karunasagar, I. (2007). Detection and characterization of Salmonella associated with tropical seafood. Int. J. Food Microbiol. 114, pp. (227-233).

Sharma, A., Singh, SK., \& Bajpai, D. (2010). Phenotypic and genotypic characterization of Shigella spp. with reference to its virulence genes and antibiogram analysis from river Narmada. Microbiol. Res. 165, pp. (33-42)

Shuber, AP., Skoletsky, J., Stern, R., \& Handelin, BL. (1993). Efficient 12-mutation testing in the CFTR gene: A general model for complex mutation analysis. Hum. Mol. Genet. 2, pp. (153-158)

Sidhu, JPS., \& Toze, SG. (2009). Human pathogens and their indicators in biosolids: a literature review. Environ. Int. 35, pp. (187-201)

Srikantiah, P., Girgis, FY., Luby, SP., Jennings, G., Wasfy, MO., \& Crump, JA. (2006). Population-based surveillance of typhoid fever in Egypt. The Amer. J. Trop. Med. Hyg. 74, pp. (114-119)

Steinert, M., Hentschel, U., \& Hacker, J. (2002). Legionella pneumophila: an aquatic microbe goes astray. FEMS Microbiol. Rev. 26, pp. (149-162).

Stewart, J.R., Gast, R.J., Fujioka, R.S., Solo-Gabriele, H.M., Meschke, J.S., Amaral-Zettler, L.A., Del Castillo, E., Polz, M.F.,

Straub, TM., Dockendorff, BP., Quinonez-Diaz, MD., Valdez, CO., Shutthanandan, JI., Tarasevich, BJ., Grate, JW., \& BrucknerLea, CJ. (2005). Automated methods for multiplexed pathogen detection. J. Microbiol. Methods, 62 (3), pp. (303-316)

Syposs, Z., Reichart, O., \& Meszaros, L., 2005. Microbiological risk assessment in the beverage industry. Food Control, 16, 6, pp. (515-521)

Szákal, D., Schneider, G., \& Pál, T. (2003). A colony blot immune assay to identify enteroinvasive Escherichia coli and Shigella in stool samples. Diagn. Microbiol. Infect. Dis. 45, 3, pp. (165-171)

Szewzyk, U., Szewzyk, R., Manz, W., \& Schleifer, H. (2000). Microbial safety of drinking water. Annu. Rev. Microbiol. 54, (81-127) 
Theron, J., Morar, D., Preez, MDU., Brozel, VS., \& Venter, SN. (2001). A sensitive seminested PCR method for the detection of Shigella in spiked environmental water samples. Water Res. 35, pp. (869-874)

Till, D., McBride, G., Ball, A., Taylor, K., \& Pyle, E. (2008). Large-scale freshwater microbiological study: Rationale, results and risks. J. Water and Health, 6, 4, pp. (443-460)

UNDPI. (2005). The International Decade for Action: “Water for Life" 2005-2015. United Nations Department of Public Information.

UNESCO. (2004). Water Programme for Africa, Arid and Water Scarce Zones 2004-2006.

United States Pharmacopeia Convention, Inc. (2001). The United States Pharmacopeia 25. Rockville, M.D.

Villalobo, E., \& Torres A. (1998). PCR for detection of Shigella spp. in mayonnaise. Appl. Environ. Microbiol. 64, 4, pp. (1242-5)

Watson, CL., Owen, RJ., Said, B., Lai, S., Lee, JV., Surman-Lee, S., \& Nichols, G. (2004). Detection of Helicobacter pylori by PCR but not culture in water and biofilm samples from drinking water distribution systems in England. J Appl Microbiol. 97, pp. (690-698)

Watterworth, L., Topp, E., Schraft, H., Leung, K.T., 2005. Multiplex PCR-DNA probe assay for the detection of pathogenic Escherichia coli. J. Microbiol. Methods, 60, pp. (93105)

Wesley, IV., \& Miller, GW. (2010). Arcobacter: an opportunistic human food-borne pathogen? In: Scheld, W.M., Grayson, M.L., Hughes, J.M. (Eds.), Emerging infections 9, ASM Press, Washington, DC, pp. (185-221)

Westrell, T., Ciampa, N., Boelaert, F., Helwigh, B., Korsgaard, H., Chríel, M., Ammon, A., \& Mäkelä, P. (2009). Zoonotic infections in Europe in 2007: a summary of the EFSAECDC annual report. Euro Surveill. 14 (3) pii: 19100.

WHO. (2001). Guidelines for Drinking-Water Quality, 2nd Ed. Microbiological Methods, vol.1. World Health Organization, Geneva.

WHO. (2003). Emerging Issues in Water and Infectious Disease. Geneva, Switzerland: WHO Press, World Health Organization.

WHO. (2004). Evaluation of the costs and benefits of water and sanitation improvements at the global level. WHO/SDE/WSH/04.04, Geneva.

Wilkes, G., Edge, T., Gannon, V., Jokinen, C., Lyautey, E., \& Medeiros, D., et al. (2009). Seasonal relationships among indicator bacteria, pathogenic bacteria, Cryptosporidium oocysts, Giardia cysts, and hydrological indices for surface waters within an agricultural landscape. Water Res, 43, pp. (2209-2223)

Wilton, S., \& Cousins, D. (1992). Detection and identification of multiple mycobacterial pathogens by DNA amplification in a single tube. PCR Methods Applic. 1, pp. (269273)

Wose Kinge, C., \& Mbewe, M. (2010). Characterization of Shigella species isolated from river Catchments in the North West Province of South Africa. S. Afr. J. Sci. 106, 11/12, pp. (1-4)

Wose Kinge, CN., \& Mbewe, M. (2011). PCR and sequencing assays targeting $m d h$ and gapA genes for Escherichia coli and Klebsiella bacteria species identification in river water from the North West Province of South Africa. Life Science J. 8, S1, pp. (104112) 
Yang, F., Yang, J., Zhang, X., Chen, L., Jiang, Y., Yan, Y., Tang, X., Wang, J., Xiong, Z., Dong, J., Xue, Y., Zhu, Y., Xu, X., Sun, L., Chen, S., Nie, H., Peng, J., Xu, J., Wang, Y., Yuan, Z., Wen, Y., Yao, Z., Shen, Y., Qiang, B., Hou, Y., Yu, J., Jin, Q. (2005). Genome dynamics and diversity of Shigella species, the etiologic agents of bacillary dysentery. Nucleic Acids Res. 33, 19, pp. (6445-6458)

Younes, M., \& Bartram, J. (2001). Waterborne health risks and the WHO perspectives. Int. J. Hyg. Environ. Health, 204, pp. (255-263) 


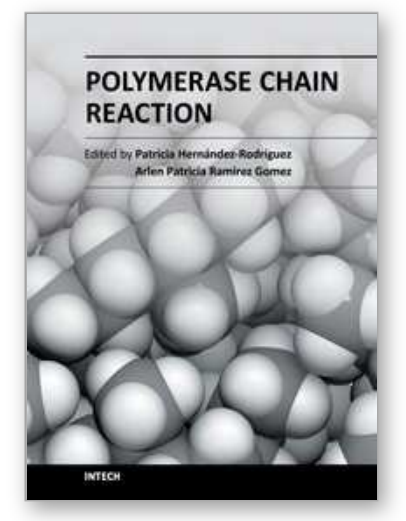

\author{
Polymerase Chain Reaction \\ Edited by Dr Patricia Hernandez-Rodriguez
}

ISBN 978-953-51-0612-8

Hard cover, 566 pages

Publisher InTech

Published online 30, May, 2012

Published in print edition May, 2012

This book is intended to present current concepts in molecular biology with the emphasis on the application to animal, plant and human pathology, in various aspects such as etiology, diagnosis, prognosis, treatment and prevention of diseases as well as the use of these methodologies in understanding the pathophysiology of various diseases that affect living beings.

\title{
How to reference
}

In order to correctly reference this scholarly work, feel free to copy and paste the following:

C. N. Wose Kinge, M. Mbewe and N. P. Sithebe (2012). Detection of Bacterial Pathogens in River Water Using Multiplex-PCR, Polymerase Chain Reaction, Dr Patricia Hernandez-Rodriguez (Ed.), ISBN: 978-953-51-06128, InTech, Available from: http://www.intechopen.com/books/polymerase-chain-reaction/detection-of-bacterialpathogens-in-river-water-using-multiplex-pcr

\section{INTECH}

open science | open minds

\author{
InTech Europe \\ University Campus STeP Ri \\ Slavka Krautzeka 83/A \\ 51000 Rijeka, Croatia \\ Phone: +385 (51) 770447 \\ Fax: +385 (51) 686166 \\ www.intechopen.com
}

\author{
InTech China \\ Unit 405, Office Block, Hotel Equatorial Shanghai \\ No.65, Yan An Road (West), Shanghai, 200040, China \\ 中国上海市延安西路65号上海国际贵都大饭店办公楼 405 单元 \\ Phone: +86-21-62489820 \\ Fax: +86-21-62489821
}


(C) 2012 The Author(s). Licensee IntechOpen. This is an open access article distributed under the terms of the Creative Commons Attribution 3.0 License, which permits unrestricted use, distribution, and reproduction in any medium, provided the original work is properly cited. 